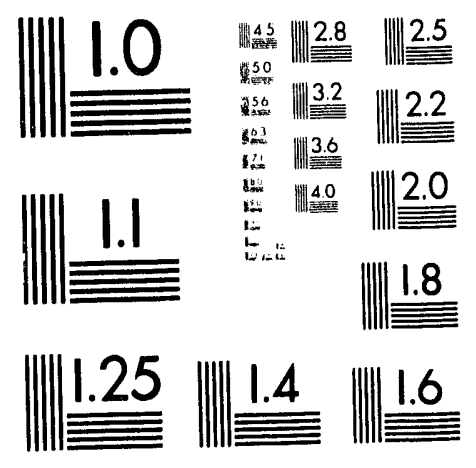



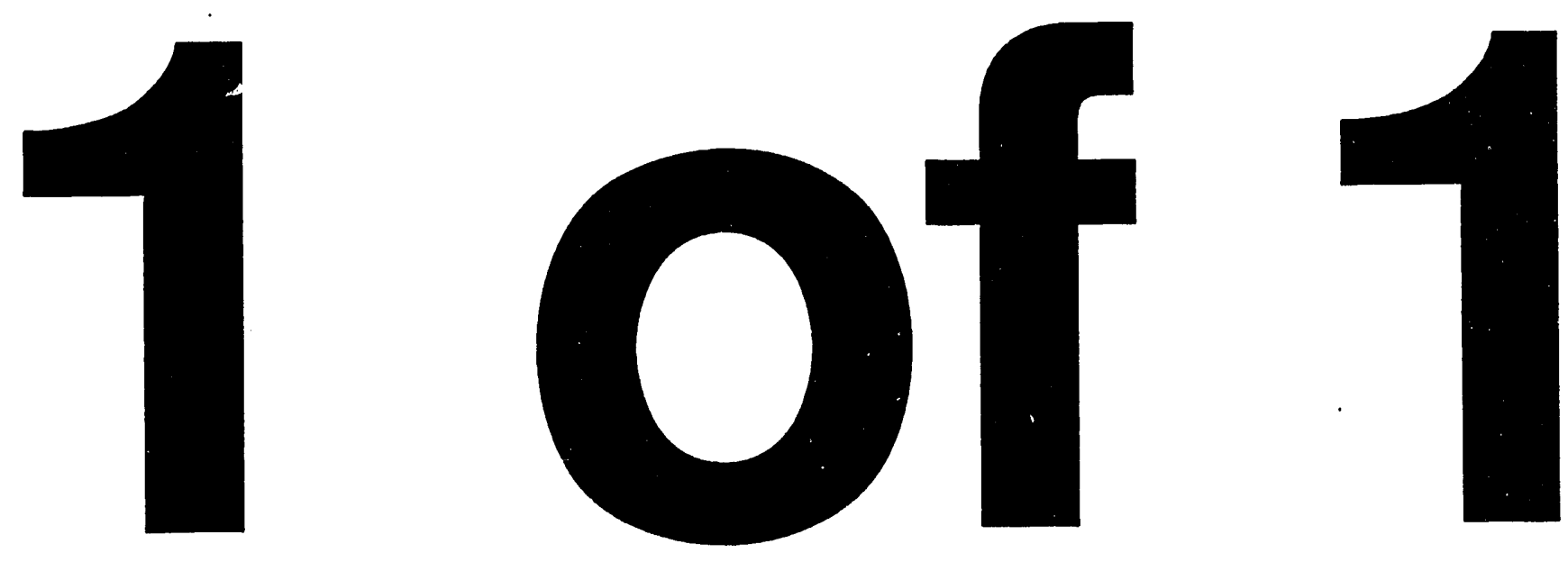
ORNL/TM-12493

Environmental Sciences Division

\section{EXPERT INITIAL REVIEW OF COLUMBIA RIVER BASIN SALMONID MANAGEMENT MODELS: SUMMARY REPORT}

Lawrence W. Barnthouse

Environmental Sciences Division

Publication No. 4164

Date Published: October 1993

Prepared for the U.S. Department of Energy

Bonneville Power Administration

(63 308610 1:NBP)

Prepared by the

OAK RIDGE NATIONAL LABORATORY

Oak Ridge, Tennessee 37831-6285

managed by

MARTIN MARIETTA ENERGY SYSTEMS, INC.

for the

U.S. DEPARTMENT OF ENERGY

under contract DE-AC05-84OR21400 


\section{CONTENTS}

\section{Page}

LIST OF TABLES $\ldots \ldots \ldots \ldots \ldots \ldots \ldots \ldots \ldots \ldots \ldots \ldots \ldots \ldots \ldots$

ABSTRACT $\ldots \ldots \ldots \ldots \ldots \ldots \ldots \ldots \ldots \ldots \ldots \ldots \ldots \ldots \ldots \ldots \ldots \ldots$

INTRODUCTION $\ldots \ldots \ldots \ldots \ldots \ldots \ldots \ldots \ldots \ldots \ldots \ldots \ldots \ldots \ldots \ldots$

SUMMARY OF MODEL EVALUATIONS $\ldots \ldots \ldots \ldots \ldots \ldots \ldots \ldots$

SUITABILITY FOR SPECIFIC MANAGEMENT APPLICATIONS $\ldots \ldots \ldots .4$

Estimating Relative Change in Juvenile Survival for Different

Downstream Passage Management Strategies $\ldots \ldots \ldots \ldots \ldots \ldots \ldots$

Estimating Adult Escapement Trends and the Probability of a

Population Falling Below a Critical Level $\ldots \ldots \ldots \ldots \ldots \ldots \ldots \ldots$

Evaluating Risk of Extinction of Weak Stocks Relative to

Alternative Life Stage Conditions $\ldots \ldots \ldots \ldots \ldots \ldots \ldots \ldots \ldots$

Evaluating Alternative Strategies for Recovery or Conservation

of Threatened or Endangered Salmon Stocks $\ldots \ldots \ldots \ldots \ldots \ldots$

Application to Multiple Stocks Within the Columbia River Basin $\ldots \ldots \ldots \ldots 7$

GENERAL ASPECTS OF MODEL PERFORMANCE $\ldots \ldots \ldots \ldots \ldots \ldots$

Ability to Simulate Biological/Life History Conditions and

Responses to Changing Conditions $\ldots \ldots \ldots \ldots \ldots \ldots \ldots \ldots \ldots$

Ability to Account for Risks and Uncertainties Resulting from

Environmental Variation and Data Inaccuracies $\ldots \ldots \ldots \ldots \ldots \ldots$

Data Limitations and Research Recommendations for Improvement $\ldots \ldots \ldots 8$

GENERAL CONCLUSION AND RECOMMENDATION $\ldots \ldots \ldots \ldots \ldots \ldots \ldots$

FUTURE DIRECTIONS $\ldots \ldots \ldots \ldots \ldots \ldots \ldots \ldots \ldots \ldots \ldots$

BIBLIOGRAPHY OF DOCUMENTS AVAILABLE TO REVIEWERS $\ldots \ldots \ldots 11$ 


\section{LIST OF TABLES}

Page

1 List of life-cycle and fish-passage model combinations reviewed $\ldots \ldots \ldots \ldots \ldots$

2 Characteristics of the life-cycle models $\ldots \ldots \ldots \ldots \ldots \ldots \ldots \ldots \ldots \ldots \ldots$

3 General characteristics of the downstream passage models $\ldots \ldots \ldots \ldots \ldots \ldots \ldots$ 


\begin{abstract}
BARNTHOUSE, L. W. 1993. Expert initial review of Columbia River Basin salmonid models: Summary report. ORNL/TM-12493. Oak Ridge National Laboratory, Oak Ridge, Tennessee. $17 \mathrm{pp}$.
\end{abstract}

Over the past years, several fish passage models have been developed to examine the downstream survival of salmon during their annual migration through the Columbia River reservoir system to below Bonneville Dam. More recently, models have been created to simulate the survival of salmon throughout their entire life cycle. The models are used by various regional agencies and native American tribes to assess impacts of dam operation, harvesting, and predation on salmonid abundance. These models are now also being used to assess extinction probabilities and evaluate restoration alternatives for threatened and endangered salmonid stocks.

Oak Ridge National Laboratory (ORNL) coordinated an initial evaluation of the principal models by a panel of outside, expert reviewers. ORNL's role consisted of (1) nominating a slate of reviewers for approval by the project sponsors and other participating agencies, (2) managing the payment of fees to the reviewers, and (3) preparing a summary of the reviewers' comments on the models.

None of the models were unequivocally endorsed by any reviewer. Significant strengths and weaknesses were noted for each with respect to reasonability of assumptions and equations, adequacy of documentation, adequacy of supporting data, and calibration procedures. Although the models reviewed differ in some important respects, all reflect a common conceptual basis in classical population dynamic theory and a common empirical basis consisting of the available time series of salmonid stock data (e.g., escapement estimates and redd counts), hydrographic records, experimental studies of dam passage parameters, and measurements of reservoir mortality.

The results of this initial review are not to be construed as a comprehensive scientific peer review of existing Columbia River Basin (CRB) salmon population models and data. The peer review process can be enhanced further by a dynamic exchange regional modelers and scientific panel experts involving interaction and feedback. To this end, a philosophy of interactive feedback and exchange of information will be incorporated into a second-phase 
comprehensive peer review process. The second-phase peer review process is expected to begin in October 1993 and will be coordinated by ORNL. 


\section{INTRODUCTION}

Over the past years, several fish passage models have been developed to examine the downstream survival of salmon during their annual migration through the Columbia River reservoir system to below Bonneville Dam. The regional entities that are developing and applying these models include Bonneville Power Administration (BPA), Columbia River InterTribal Fisheries Commission, Idaho Fish and Game, National Marine Fisheries Service, Northwest Power Planning Council, Oregon Department of Fish and Game, Washington Department of Fisheries, U.S. Forest Service, Resources for the Future, and the University of Washington. More recently, models have been created to simulate the survival of salmon throughout their entire life cycle; this includes hatchery and natural egg-to-smolt survival, downstream migration, ocean residence, and upstream migration of adults returning to spawning grounds of origin.

The models are used by various regional agencies and native American tribes to assess impacts of dam operation, harvesting, and predation on salmonid abundance. These models are now also being used to assess extinction probabilities and evaluate restoration alternatives for threatened and endangered salmonid stocks. On the supposition that regional interests could be best served during this dynamic period by subjecting salmon fish models to a rigorous scientific peer review process, Oak Ridge National Laboratory (ORNL) coordinated an initial evaluation of the principal models by a panel of outside, expert reviewers.

ORNL's role consisted of (1) nominating a slate of reviewers for approval by the project sponsors and other participating agencies, (2) managing the payment of fees to the reviewers, and (3) preparing a summary of the reviewers' comments on the models. The expert reviewers were charged with reviewing the models with respect to their suitability for the following purposes:

- estimating the relative change in juvenile survival for different downstream passage management strategies,

- estimating adult escapement trends and the probability of a population to fall below a critical level,

- evaluating the risk of extinction of weak stocks relative to alternative life-stage conditions, 
- evaluating alternative strategies for recovery or conservation of threatened or endangered salmon stocks, and

- application to multiple stocks within different regions of the Columbia River Basin.

In addition, the reviewers were asked to evaluate the following general aspects of model performance:

- ability to simulate biological/life history conditions and species responses to changing conditions through appropriate theory, analytical concepts, and statistical methods;

- ability to account for analytical risk and uncertainty resulting from environmental variation and data inaccuracies; and

- data limitations and research recommendations tor improvements.

It should be noted that, although the above objectives and performance criteria are all relevant to the general goal of managing and restoring Columbia River Basin salmonid stocks, none of the models reviewed were designed to address every objective. Some models had more limited objectives than others, or they emphasized different objectives. It is unreasonable to expect any single model to adequately address all of them. The models included in the review are listed in Table 1. The documentation provided to the reviewers is listed in the References section. The four experts who participated in the review were:

- Dr. Saul Saila, Emeritus Professor of Oceanography, University of Rhode Island;

- Drs. Richard Deriso and Alejandro Anganuzzi, Inter-American Tropical Tuna Commission;

- Drs. James F. Kitchell and Stephen Carpenter, University of Wisconsin; and

- Dr. Louis Botsford, University of California, Davis.

The anonymity of reviewers' is preserved by means of a number designation used to reference comments throughout the report. 


\section{SUMMARY OF MODEL EVALUATIONS}

None of the models were unequivocally endorsed by any reviewer. Significant strengths and weaknesses were noted for each with respect to reasonability of assumptions and equations, adequacy of documentation, adequacy of supporting data, and calibration procedures. As noted in Table 1, the models can be divided into two classes: life-cycle models and downstream passage models. The life-cycle models simulate the populationdynamic processes of reproduction, growth, and survival and are used to project long-term population trends and consequences of management actions. Table 2 summarizes the general characteristics of the three life-cycle models reviewed.

Table 1. List of life-cycle and fish-passage model combinations reviewed

\begin{tabular}{llll}
\hline Life-cycle model & $\begin{array}{c}\text { Stochastic Life } \\
\text { Cycle Model } \\
\text { (SLCM) }\end{array}$ & $\begin{array}{c}\text { System Planning } \\
\text { Model (SPM) }\end{array}$ & $\begin{array}{c}\text { Empirical Life Cycle } \\
\text { Model (ELCM) }\end{array}$ \\
$\begin{array}{l}\text { Relevant documents } \\
\text { Fish-passage model }\end{array}$ & $\begin{array}{l}{[6],[7],[9]} \\
\text { Columbia River } \\
\text { Salmon Passage } \\
\text { Model (CRiSP) }\end{array}$ & $\begin{array}{c}\text { Passage Analysis } \\
\text { Model (PAM) and } \\
\text { Mainstream Passage } \\
\text { Module (MPM) }\end{array}$ & $\begin{array}{c}\text { Fish Leaving Under } \\
\text { Several Hypotheses } \\
\text { (FLUSH) }\end{array}$ \\
$\begin{array}{l}\text { Relevant documents } \\
\text { Documents describing } \\
\text { applications }\end{array}$ & {$[1],[2],[3],[4],[5],[8]$} & {$[10],[11]$} & {$[12],[14],[15]$} \\
\hline
\end{tabular}

${ }^{a}$ The numbers refer to the set of documents received for review.

The downstream passage models simulate the movement of smolts from their natal streams to the mouth of the Columbia River. These models are used to quantify the influence of reservoir operations, dam passage, and predation on the survival of migrating smolts. The general characteristics of these models are summarized in Table 3. The models are paired in actual applications. For example, the Stochastic Life-Cycle Model (SLCM) and the Columbia River Salmon Passage Model (CRiSP) are intended to be used together. Similarly, the System Planning Model (SPM) is paired with the Passage Analysis Model (PAM) and the 
Table 2. Characteristics of the :ife-cycle models

\begin{tabular}{|c|c|c|c|}
\hline & SPM & SLCM & ELCM \\
\hline Basic structure & $\begin{array}{l}\text { Age-structured } \\
\text { forward cohort } \\
\text { model }\end{array}$ & $\begin{array}{l}\text { Age-structured } \\
\text { forward cohort } \\
\text { model with } \\
\text { stochastic }\end{array}$ & $\begin{array}{l}\text { Age-structured } \\
\text { forward cohort } \\
\text { model incorpat } \\
\text { ing variability } \\
\text { from a parameters } \\
\text { time series of } \\
\text { empirical survival } \\
\text { scalars }\end{array}$ \\
\hline Natural-hatchery stocks & Yes & Yes & Yes \\
\hline $\begin{array}{l}\text { Density-dependent } \\
\text { transition }\end{array}$ & Egg-to-smolt stage & Egg-to-smolt stage & $\begin{array}{l}\text { Adults to age- } 1 \\
\text { recruits }\end{array}$ \\
\hline $\begin{array}{l}\text { Stock-recruitment } \\
\text { function }\end{array}$ & Beverton-Holt & Various options & Ricker \\
\hline Uncertainty in parameters & Partial & Yes & Partial \\
\hline Calibration of parameters & $\begin{array}{l}\text { Based on escape- } \\
\text { ments }\end{array}$ & $\begin{array}{l}\text { Based on escape- } \\
\text { ments and observed } \\
\text { variance of egg-to- } \\
\text { adult survival }\end{array}$ & $\begin{array}{l}\text { Based on escape- } \\
\text { ments, exploita- } \\
\text { tion rates, and } \\
\text { adult passage } \\
\text { survival rates }\end{array}$ \\
\hline $\begin{array}{l}\text { Parameters estimated in } \\
\text { calibration }\end{array}$ & $\begin{array}{l}\text { Estuary survival } \\
\text { rate, stochastic } \\
\text { modulator, and } \\
\text { intrinsic productivity }\end{array}$ & $\begin{array}{l}\text { Adult recovery } \\
\text { rate and its } \\
\text { coefficient of } \\
\text { variation }\end{array}$ & $\begin{array}{l}\text { Relative survival } \\
\text { indices }\end{array}$ \\
\hline
\end{tabular}

Empirical Life Cycle Model (ELCM) is paired with the Fish Leaving Under Several Hypotheses (FLUSH) model. Multiple versions of several of the models were reviewed; except as noted the comments in the following refer to all versions of the model being discussed.

\section{SUITABILITY FOR SPECIFIC MANAGEMENT APPLICATIONS}

\section{Estimating Relative Change in Juvenile Survival for Different Downstream Passage Management Strategies}

This modeling objective relates primarily to the downstream passage models (CRiSP, PAM, and FLUSH). The reviewers agree that all three models are suitable for this purpose, although all have limitations. Mortality resulting from dam passage is modeled essentially the same in all of the models, although CRiSP includes more detailed representations of the 
Table 3. Gencral characteristics of the downstream passage models

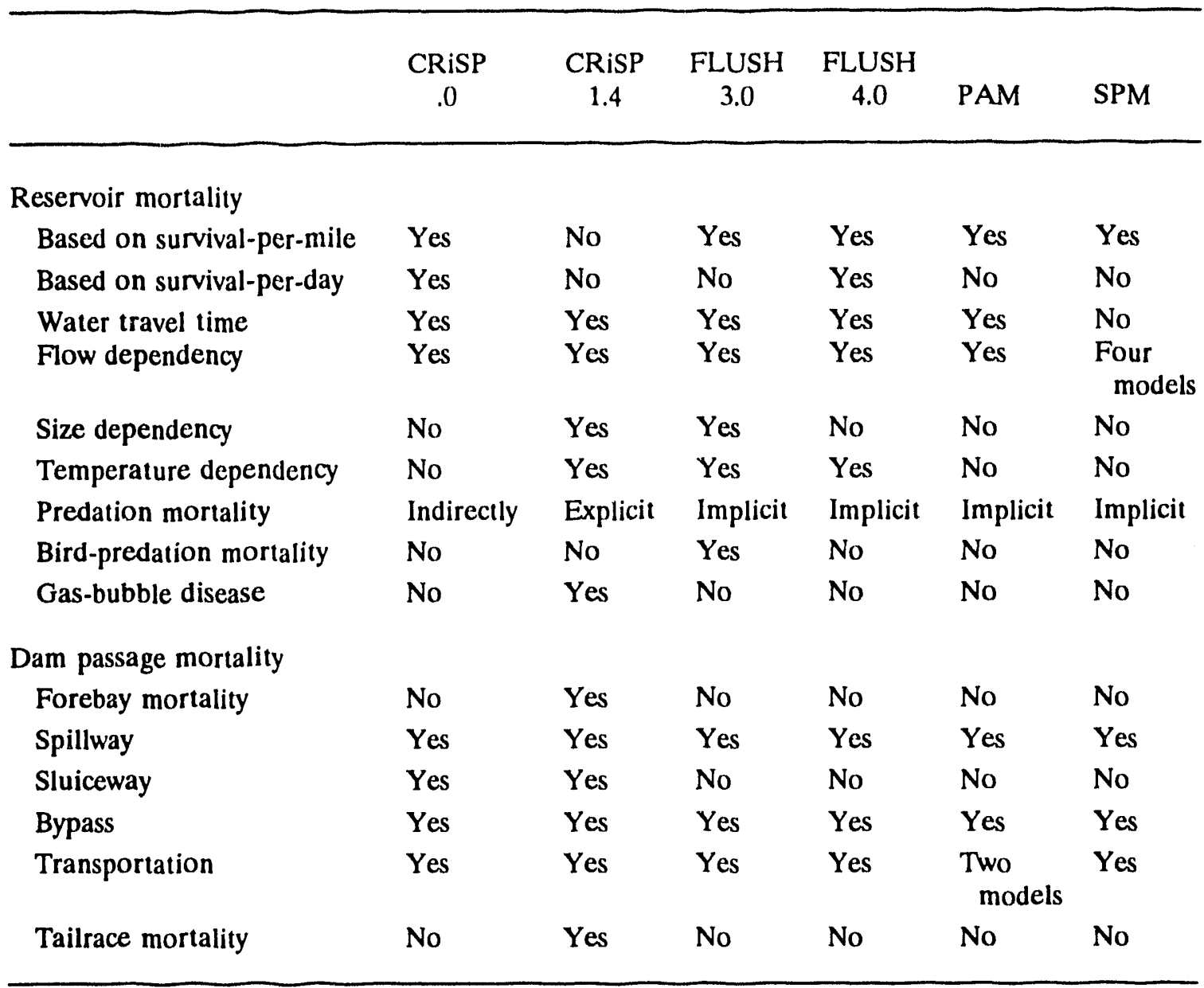

passage process. There were more substantive differences regarding modeling of downstream migration and in-reservoir mortality. One version of CRiSP (CRiSP 1.4) includes an explicit model of predation mortality; the others assume that mortality is a simple function of reservoir residence time (determined by reservoir length and turnover time) and (for FLUSH ?) temperature. However, to the extent that the models employ common data sets, the real differences between the models as currently applied may be smaller than the potential differences indicated by examination of the equations and computer codes. The calibrated parameter values for all spring/summer chinook simulations, for example, are based on the same study. The empirical support and realism of the mechanisms included in CRiSP 1.4 were questioned by reviewers 1 and 4; the general adequacy of the approaches used in all of the models for quantifying the dam passage parameters was questioned by reviewer 2 . 
Estimating Adult Escapement Trends and the Probability of a Population Falling Below a Critical Level

This objective is relevant only to the three life-cycle models. Reviewer 4 noted that trend analysis was not explicitly identified as an objective of any of the models. However, judged on the basis of the available documentation, the general consensus of the reviewers was that all three can be used to quantify adult escapement trends, provided that future environmental conditions and harvesting regimes remain similar to those extant during the years for which historical records are available. The reason for this limitation is the reliance of all models on year-specific empirical "scalars" derived by calibrating the models to the historical record.

Only the SLCM was judged suitable for estimating the probability of a population falling below a critical level. The reviewer who performed the most detailed analysis of the suitability of the models for modeling the recovery or extinction of small populations (reviewer 3) found SLCM also to be inadequate compared with other available approaches for modeling the dynamics of small populations.

\section{Evaluating Risk of Extinction of Weak Stocks Relative to Alternative Life Stage Conditions}

BPA requested that SLCM be reviewed specifically under this criterion. The principal determinants of the ability of a model to evaluate risks of extinction are (1) the ability of a model to simulate the within-year and between-year variability of environmental processes influencing the abundance of small populations and (2) the availability of data for quantifying the actual variability of those processes. SLCM was judged to be suitable, in general, for evaluating risks of extinction but was found to have significant limitations because of inadequate characterization of uncertainties affecting year-to-year variability in survival rates (reviewers 1, 2, and 3). Some information relevant to evaluating risk of extinction could be obtained from all of the models. For example, the downstream passage models all would be potentially useful for evaluating how variability in reservoir migration/mortality and dam passage parameters infiuences the survival of downstream migrants. As noted in Table 2, SPM and ELCM already incorporate uncertainty in some model parameters; both could be modified to incorporate variability in others as well. 


\section{Evaluating Alternative Strategies for Recovery or Conservation}

of Threatened or Endangered Salmon Stocks

Because this objective emphasizes comparisons between alternative conditions rather than estimation of population risks, most of the reviewers found all of the models to be potentially useful. The life-cycle models would be most useful for comparing adult harvesting strategies and, in the case of SLCM, management actions aimed at enhancing early life stage survival. The downstream passage models would be most useful for evaluating reservoir operation strategies, dam modifications, and other approaches to reducing mortality during downstream migration. In principle, the models containing the most mechanistic detail (i.e., SLCM and CRiSP) would be the most useful; however, when empirical support for parameter values is lacking the predictive value of detailed mechanistic models will be no better than that of a more aggregated empirical model.

\section{Application to Multiple Stocks Within the Columbia River Basin}

All of the models were judged suitable, at least in principle, for application to multiple stocks. The limitation on performing such applications involves availability of separate data sets for each stock.

\section{GENERAL ASPECTS OF MODEL PERFORMANCE}

\section{Ability to Simulate Biological/Life History Conditions and Responses to Changing Conditions}

This feature relates to the degree of mechanistic detail in the models and the degree to which parameters have been adequately estimated. Among the life cycle models, SLCM and SPM contain relatively detailed representations of the salmonid life cycle, especially the early life stages. Consequently, these models are potentially applicable to a somewhat wider variety of conditions than is the ELCM, which does not explicitly simulate early life stages and is closely tied to stock composition data for specific stocks. If measurements of process parameters are unavailable, the two approaches are essentially equivalent.

The degree to which flexibility leads to improved understanding and predictive capability depends on the validity of the mechanistic representations and the quality of the data used for parameter estimation. Questions about both of these aspects of SLCM, CRiSP, PAM, 
and SPM were raised by reviewers. Points of particular concern included the functions and parameters used to quantify density-dependence in the life-cycle models (including ELCM) and the predation mortality function used in CRiSP 1.4.

\section{Ability to Account for Risks and Uncertainties Resulting from Environmental Variation and Data Inaccuracies}

Because of its stochastic structure, SLCM was judged by all reviewers to be the model best capable of accounting for risks and uncertaincies. It is the only model that explicitly accounts for parameter uncertainties. Uncertainties resulting from hydrologic variability are accounted for in SPM and in all of the downstream passage models. Although judged the best of the reviewed models for addressing risk and uncertainty, reviewers 1,2 , and 3 concluded that SLCM inadequately accounts for many important sources of uncertainty.

\section{Data Limitations and Research Recommendations for Improvement}

In general, the more detailed models (SLCM and CRiSP) were found to have more severe data limitations than the simpler models. Data needed to estimate parameter values for recruitment functions for all of the life cycle models were judged to be critical, but no specific recommendations for ensuring data quality were provided. (Reviewer 3 suggested that too much attention was being paid to density-dependence.) Data for estimating reservoir mortality were identified as critical in all of the downstream passage models, but especially in the highly detailed CRiSP 1.4 .

Specific recommendations for improving each of the models were made by every reviewer. Several reviewers provided additional, more general recommendations. Reviewer 2 discussed several alternatives to population-dynamic modeling that could be used to evaluate salmonid management strategies. Reviewers 1 and 4 recommended that in the future an opportunity should be provided for reviewers and modelers to interact. Reviewer 1 recommended that the different modeling groups work together to develop a common model. 


\section{GENERAL CONCLUSION AND RECOMMENDATION}

Although the models reviewed differ in some important respects, all reflect a common conceptual basis in classical population dynamic theory and a common empirical basis consisting of the available time series of salmonid stock data (e.g., escapement estimates and redd counts), hydrographic records, experimental studies of dam passage parameters, and measurements of reservoir mortality. Hence, the similarities between the models may well be more important than the differences. In particular, improvements in the key empirical data are likely to improve the performance of all the models.

The format chosen for this review was designed to maximize the independence of the reviewers' evaluations. A subsequent review phase involving direct interaction between the modelers and the reviewers would facilitate reviewer understanding of the models and better communication among the modeling groups. Whether the teams everitually develop a common set of models (as suggested by reviewer 1) or retain their separate models, this interactive approach would be an efficient means of using outside scientific expertise to improve the quantitative tools available for managing Columbia River Basin salmonid populations.

\section{FUTURE DIRECTIONS}

This initial peer review process conducted by ORNL has generated useful insights and comparisons of each model. This review was based on existing sources of documentation, some of which were in a preliminary stage of development. Although the conclusions presented here present the objective reviews of scientific panel experts, regional modeling entities understand that the results of this peer review process are not to be construed as a comprehensive scientific peer review of existing Columbia River Basin (CRB) salmon population models and data. The initial peer review did not allow regional modelers and peer review panel experts to interact. Interaction between the peer review panel and regional modelers could help to clarify some misunderstandings of the models and potentially identify other information gaps and possible improvements in regional salmon models.

The CRB regional modeling entities have agreed that this peer review process can be enhanced further by allowing regional modelers and scientific panel experts to interact and 
provide feedback in a dynamic fashion. To this end, CRB modeling entities will emphasize and incorporate this philosophy of interactive feedback and exchange of information into a second phase comprehensive peer review process. The second-phase peer review process is expected to begin in September 1993 and will again be coordinated by ORNL. 


\section{BIBLIOGRAPHY OF DOCUMENTS AVAILABLE TO REVIEWERS}

1. Anderson, D. A., and W. E. McConnaha. 1992. Effect of 1992-93 operations on spring chinook salmon in the Snake River.

2. Anonymous (Center for Quantitative Science, University of Washington). 1992. Columbia River Salmon Passage (CRiSP) Model (Version 1.3).

3. Anonymous (Center for Quantitative Science, University of Washington). 1992. Columbia River Salmon Passage (CRiSP) Model (Version 1.4).

4. Askren, D. R. 1992. Input parameters for modeling the downstream migration of Snake River wild salmon using the Columbia River Salmon Passage Model (CRiSP.1) (Version 1.3).

5. Divisic.. of Fish and Wildlife. 1993. Bonneville Power Administration, Biological modeling of Snake River chinook.

6. Fisher, T. R., D. C. Lee, and J. B. Hyman. 1995. Input parameters for the modeling of upper Snake River wild chinook salmon with the Stochastic Life-Cycle Model (SLCM).

7. Fisher, T. R. 1992. Input parameters for the modeling of Snake River salmon with the Columbia River Salmon Passage Model (CRiSP.0)

8. Fisher, T. R. 1992. Input parameters for the modeling of Snake River salmon with the Columbia River Salmon Passage Model (CRiSP.0).

9. Fisher, T. R. 1992. Input parameters for the modeling of Snake River salmon with the Columbia River Salmon Passage Model (CRiSP.0)

10. Fisher, T. R., D. C. Lee, and J. B. Hyman. 1992a. Input parameters for the modeling of upper Snake River wild chinook salmon with the Stochastic Life-Cycle Model (SLCM).

11. Fisher, T. R., D. C. Lee, and J. B. Hyman. 1992b. Input parameters for the modeling of upper Snake River wild chinook salmon with the Stochastic Life-Cycle Model (SLCM).

12. Hinrichsen, R. T., J. Frever, D. A. Anderson, G. Swartzman, and B. Sherer. 1992. Columbia River Salmon Passage (CRiSP) Model Documentation for CRiSP.0.

13. Lee, D. C., and J. B. Hyman. 1992. The Stochastic Life-Cycle Model (SLCM): Simulating the population dynamics of anadromous salmonids. 
14. McConnaha, W. E., and D. A. Anderson. 1992. Analysis of rebuilding options for Snake River spring chinook salmon.

15. Monitoring and Evaluation Group. 1989. System Planning Model Documentation.

16. Schaller, H., and T. Cooney. 1992. Note: 4 appendices: Snake River naturally spawning fall chinook run reconstruction at lower Granite Dam; Snake River fall chinook supplementation; Pacific Salmon Commission Chinook Model Documentation. FLUSH 3.0 juvenile passage model documentation. Snake River Chinook Life Cycle Simulation Model for Recovery and Rebuilding Plan Evaluation (Draft).

17. Schaller, H., P. Petrosky, W. Weber, and T. Cooney. 1992. Snake River Spring/Summer Chinook Life-Cycle Simulation Model for Recovery and Rebuilding Plan Evaluation (DRAFT).

18. T.E.C.H. Committee. 1992. An analytical assessment of current management actions on Snake River spring and summer chinook.

19. T.E.C.H. Committee. 1992. An analytical assessment of current management actions on Snake River fall chinook (DRAFT).

20. Weber, E., and C. Petrosky. 1992. The FLUSH computer simulation model.

21. Weber, E., C. Petrosky, and H. Schaller. 1992. FLUSH Version 4.0. 
ORNL/TM-12493

\section{INTERNAL DISTRIBUTION}

1-10. L. W. Barnthouse

11. L. D. Bates

12. G. F. Cada

13. C. C. Coutant

14. J. H. Cushman

15. D. E. Fowler

16. C. W. Gehrs

17. S. H. Hildebrand

18. P. Kanciruk

19. D. E. Reichle
20. M. J. Sale

21. F. E. Sharples

22. D. S. Shriner

23. S. H. Stow

24. Central Research Library

25-39. ESD Library

40-41. Laboratory Records Department

42. Laboratory Records, ORNL-RC

43. ORNL Patent Section

44. ORNL Y-12 Technical Library

\section{EXTERNAL DISTRIBUTION}

45. R. N. Farvolden, Professor, Department of Earth Sciences, University of Waterloo, Waterloo, Ontario N2L 3G1 CANADA

46. R. C. Harriss, Institute for the Study of Earth, Oceans, and Space, Science and Engineering Research Building, University of New Hampshire, Durham, NH 03824

47. G. Y. Jordy, Director, Office of Program Analysis, Office of Energy Research, ER-30, G-226, U.S. Department of Energy, Washirigton, DC 20545

48-147. Charles R. Korson, Bonneville Power Administration Coordination and Review-Pb, P.O. Box 3621, Portland, OR 97208

148. A. Patrinos, Director, Environmental Sciences Division, Office of Health and Environmental Research, ER-74, U.S. Department of Energy, Washington, DC 20585

149. F. J. Wobber, Environmental Sciences Division, Office of Health and Environmental Research, ER-74, U.S. Department of Energy, Washington, DC 20585

150. Office of Assistant Manager for Energy Research and Development, U.S. Department of Energy Oak Ridge Operations, P.O. Box 2001, Oak Ridge, TN 37831-8600

151-152. Office of Scientific and Technical Information, P.O. Box 62, Oak Ridge, TN 37831 

